\title{
NOTES.
}

\section{SPORANGIA ATTRIBUTED TO BOTRYOPTERIS ANTIQUA, KID.}

STON.-Botryopteris antiqua, the most ancient and simplest species of the genus, was first described by Mr. R. Kidston, F.R.S., in I $908,{ }^{1}$ from the well-known plantbearing bed, of Lower Carboniferous age, at Pettycur, near Burntisland. The petioles and smaller branches of the rachis are common in the Pettycur material, though the stems are not often met with. M. F. Pelourde has recently identified the species in the 'Culm' of Esnost, near Autun.' Associated with the petioles we commonly find small sporangia, quite similar to those which so usually occur with the Coal-measure species $B$. hirsuta and $B$. ramosa, ${ }^{3}$ but somewhat smaller. The sporangia are of an approximately spherical form ; the wall is one cell thick and provided with a broad plate of enlarged cells resembling the areola or false annulus of the Osmundaceae. Sporangia of this type have often been observed in petrifactions of Carboniferous age ; they have recently been described and figured by M. Pelourde, from the same block in which he found the Autun specimens of Botryopteris antiqua." He does not venture to draw any conclusion as to the plant to which the sporangia belonged, though the probability of their connexion with the Botryopteris was evidently present to his mind. Neither has there been, as yet, any decisive ground, apart from analogy, for specially connecting the Pettycur sporangia with the associated Botryopteris.

In examining a section, cut by Mr. W. Hemingway from a block of my Pettycur material, I observed a group of the sporangia in question in such close association with a rachis of Botryopteris antiqua as to strongly suggest a connexion between them. The sporangia are four in number and are ranged in a quadrangular group, as shown in the sketch, immediately opposite a small Botryopteris rachis, the upper surface of which is turned towards them. The whole arrangement is exceedingly definite and appears unlikely to be accidental. The sporangia are well preserved; in each of them the characteristic multiseriate annulus is conspicuous (see Figure). They are full of spores, many of which have a marked triangular form, probably exaggerated by contraction, just as is the case in the spores of the sporangia associated with $B$. ramosa. ${ }^{5}$ The flat plate of cells (marked $i$ in the Figure) lying between two of the sporangia suggests a kind of indusium; it will be remembered that an elaborate

1 On a new species of Dineuron and of Botryopteris from Pettycur, Fife. Trans. Roy. Soc., Edinburgh, vol. xlvi, Part II, No. 16, 1908.

2 Observations sur quelques végétaux fossiles de l'Autunois. Ann. Sci. Nat., Bot., 9 $9^{\circ}$ série, t. xi, rgro.

${ }_{3}$ D. H. Scott, Studies in Fossil Botany, p. 332, Figs. I 24 and I 25,2 nd ed., I908.

4 Pelourde, 1. c., p. 367 , Figs. 6 and 7 .

5 Scott, 1. c., Fig. 125.

Annals of Botany, Vol. XXIV. No. CXVI. October, I9ro.] 
indusium was described by Renault in $B$. forensis, ${ }^{1}$ but the subject is one that requires further investigation before any conclusion can be drawn.

The diameter of the sporangia in the Pettycur specimen is from $280 \mu$ to $240 \mu$; that of the spores about $25 \mu$, and that of the annulus cells from $5 \circ \mu$ to $60 \mu$.

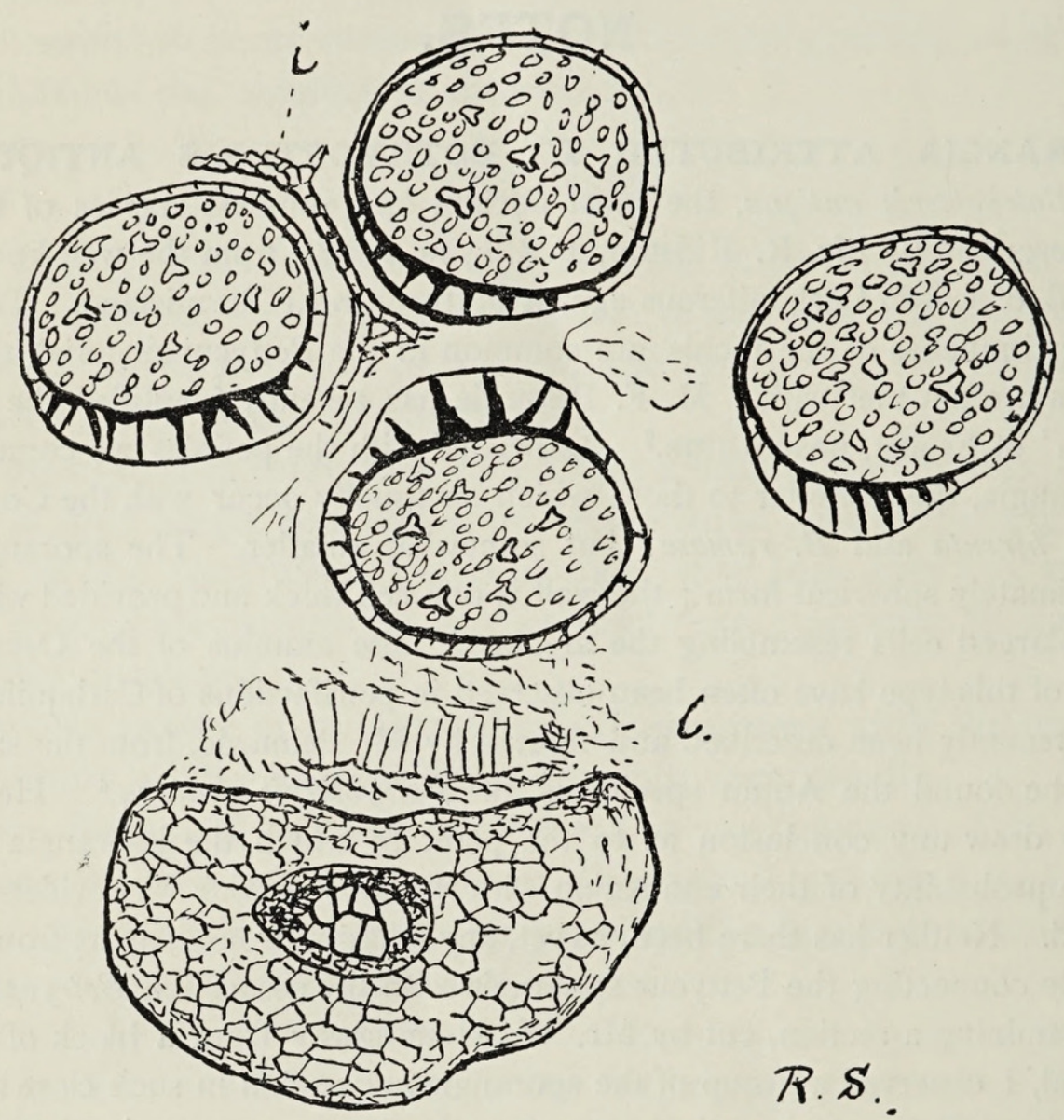

Group of four annulate sporangia in close association with a rachis of Botryopteris antiqua. $i$, indusium-like structure between two sporangia. (The palisade tissue at $l$ is a foreign body, being a fragment of the sporangium-wall of Lepidostrobus Veltheimianus.) Drawn by Mrs. D. H. Scott, F.L.S. $x$ about roo. (Scott Coll. 2496.)

The specimen just described appears to heighten the probability that the sporangia of an Osmundaceous type associated with Botryopteris antiqua really belonged to that plant; it thus seems worth placing on record, though evidence of actual continuity is still lacking.

D. H. SCOTT.

OAKLEY, HANTS.

${ }^{1}$ Bassin Houiller et Permien d'Autun et d'Épinac. Flore Fossile, $2^{\mathrm{e}}$ partie, p. 54, Figs. 22 and 23,1896 . 


\section{$2 \mathrm{BHL}$ Biodiversity Heritage Library}

Scott, Dukinfield Henry. 1910. "Sporangia attributed to Botryopteris antiqua, Kidston." Annals of botany 24, 819-820.

https://doi.org/10.1093/oxfordjournals.aob.a089306.

View This Item Online: https://www.biodiversitylibrary.org/item/262605

DOI: https://doi.org/10.1093/oxfordjournals.aob.a089306

Permalink: https://www.biodiversitylibrary.org/partpdf/319814

\section{Holding Institution}

New York Botanical Garden, LuEsther T. Mertz Library

\section{Sponsored by}

BHL-SIL-FEDLINK

\section{Copyright \& Reuse}

Copyright Status: Public domain. The BHL considers that this work is no longer under copyright protection.

This document was created from content at the Biodiversity Heritage Library, the world's largest open access digital library for biodiversity literature and archives. Visit BHL at https://www.biodiversitylibrary.org. 